\title{
CONSIDERAÇÕES SOBRE AGAMBEN ${ }^{1}$ CONSIDERATIONS ABOUT AGAMBEN
}

\author{
LUIZ HEBECHE \\ (UFSC / Brasil)
}

\begin{abstract}
RESUMO
Giorgio Agamben em pequenos artigos, entrevistas e baixo-assinados tem chamado a atenção para o estado de abandono do povo palestino, mas curiosamente esse assunto não é tratado em suas obras mais importantes. Em Homo sacer, por exemplo, ele retoma o termo "muçulmano", comumente empregado pelos prisioneiros dos campos de concentração como a expressão do maior abandono possível da existência humana, mas não reflete suficientemente sobre a origem dessa palavra, isto é, de que nessa expressão já se encontrava o ódio e o desprezo do sionismo, não só entre os próprios prisioneiros, mas pelo povo palestino e pelos árabes em geral. A seguir comentaremos brevemente algumas obras desse autor que, dando continuidade à ideologia da vitimação, faz com que, mais uma vez, o passado inominável acabe encobrindo o presente abominável.
\end{abstract}

Palavras-chave: Agamben; Palestina; ideologia

\begin{abstract}
In small articles, interviews and undersigned, Giorgio Agamben have called attention to the state of disrepair of the Palestinian people, but oddly this is not handled in his most important works. In Homo sacer, for example, incorporates the term "Muslim", commonly used by prisoners of concentration camps as the expression of the greatest possible abandonment of human existence, but does not reflect sufficiently about the origin of this word, that is, that in this expression we already found the hatred and contempt of Zionism, not only between the prisoners, but for the Palestinian people and the Arabs in General. Below we briefly some works of this author that, continuing to the ideology of victimization, make once again that the unspeakable past ends up covering up the abominable present.
\end{abstract}

Key-words: Agamben; Palestina; ideology

Em A linguagem e a morte, ${ }^{2}$ Agamben procurou, seguindo os passos de Derrida, mais uma vez, confrontar a metafísica. Se para Heidegger o pensamento originário é o do Seer (Seyn), isto é, a diferença ontológica pensada enquanto tal, para Derrida subjaz à diferença ontológica, o pensamento do traço, para Agamben, por sua vez, trata-se de levar adiante a crítica fonocêntrica realçando o que chama de pensamento da Voz. Ou seja, se para Derrida o fonocentrismo encobria a escritura, para este a Voz é o shifter supremo, isto é, a instância que guarda o segredo do maior mistério e que diz respeito à conexão entre língua e fala, consciência e discurso, dizer e falar. Essa noção, aliás, também se encontra em Gilles Deleuze que entende que a univocidade do ser significa também que o ser é a Voz. Ou seja, univocidade quer dizer "a identidade do atributo 
noemático e do expresso linguístico: acontecimento e sentido". ${ }^{3}$ Esse extra-ser, que não pode ser conhecido nem pelas ciências nem pelas filosofias, é o pensamento da Voz. Ora, uma vez mostrado que todo o pensamento até então "pensamento da Voz", pode-se então entendê-lo como uma figura do passado que agora dá vez à "nossa voz, pois o que fala isto é o ethos". O que se diz só porque se fala pode ser dito. Ou seja, a morada habitual do homem é, portanto, essa voz originária uma vez que ela é o que nos há de mais íntimo; daí que pode ser chamada de "nossa voz". Ora, isso significa que tudo foi antes e será depois a "nossa voz" e que, portanto, ela não aparece simplesmente a posteriori, pois já sempre esteve em execução. Não fosse assim como poder-se-ia chegar até ela? Isto é, cumpre, de início, notar que nesse livro Agamben começa com os pronomes demonstrativos hegelianos que se encontram no capítulo sobre a certeza sensível de a Fenomenologia do espírito, mas para mostrar a dificuldade que envolve o ato de dizer as coisas e do abismo que separa o dizer do que é dito; e, retomando escritos circunstanciais do jovem Hegel, ele aproveita para remeter o significado desses pronomes para os misteriosos abismos eleusinos. $^{4}$

Em seu livro, o tratamento que Agamben dá à morte e à negatividade deixa a desejar. $\mathrm{O}$ tema é tratado de modo muito sucinto em seu debate com Hegel e Heidegger, o que, aliás, demandaria maiores detalhes que não se encontram no modo puramente circunstancial e afoito. Agamben, como lhe é usual, cita uma passagem do Heidegger posterior à reviravolta do pensar (Kehre), mas não explora o que vem a ser a morte nessa virada heideggeriana. Ele volta a situarse em Ser e tempo (SZ), ${ }^{5}$ mas sua abordagem da obra, porém, é feita de um modo em que vão se imiscuindo os fenômenos do silêncio, a voz da consciência e a morte. Quando o tema começa a destacar-se ele logo ocupa-se com a problemática da morte em Hegel, onde esta é representada pela voz primitiva do animal que morre. Mas não é a morte hegeliana antes de tudo expressa em diversas figuras eternas do espírito? O que então autorizaria Agamben a operar assim? Como "pós-metafísico" estaria levando ao pé da letra a advertência heideggeriana que no fim da filosofia restariam apenas relatos epigonais? Ora, seja como for, sua autorização é dada, nesse livro, por uma espécie de chave de interpretação: a rejeição do pensamento da Voz, ou seja, da crítica a esse absoluto que se antecipa e permite que os outros pensamentos sejam enunciados. Marcada pelo niilismo ocidental, essa voz - super-shifter -

não mais animal, mas ainda não humano, não mais o desejo e não ainda trabalho, a pura negatividade do gozo do senhor apresenta-se como ponto no qual se mostra, por um 
instante, a articulação originária daquela faculdade da morte que caracteriza a consciência humana" (AGAMBEN, 2006, p. 69).

Ora, como o assunto é a morte e como qualquer significação é um ainda-não, isto é, a morte só pode ser dita negativamente à medida que, nesse caso, a Voz é voz da morte. E o que valeria para Hegel, vale também para morte em SZ. Mas se se tratasse da "vida", embora não tendo a negatividade da morte, não seria também da Voz da vida? Ou seja, Agamben tendo a chave interpretativa do "pensamento da Voz" acredita abrir todas as portas com ela, o que resulta procedimentos forçados e dogmáticos onde equipara, partindo desse fundo comum, dois absolutos: o saber absoluto hegeliano e o acontecimento-apropriador (Ereignis) heideggeriano. É claro que sua leitura apropria-se aqui da noção do "pensamento do Seer", que, via Derrida, culmina no "pensamento da Voz". ${ }^{6}$ E, ao seu modo, como a efetiva clausura da metafísica.

No fim da metafísica como pensamento da voz mostra-se mais claramente que morada habitual do homem é o ethos. O fim do pensamento da voz leva com ele também a saudade da terra do nunca. Ou seja, não há mais necessidade de rememorar o que já foi. Mas se a história da metafísica se clausura, não ocorre o mesmo com a antropologia cultural e histórica, porque o ethos que surge agora não é menos violento que o da era do pensamento da Voz, pois o que nele se descobre é que a morada habitual do homem está comprometida com a violência originária do homo sacer. E assim, a despedida da metafísica na "nossa voz" mostra que o ser que não podia ser nominado no Ereignis, ou que havia se completado no absoluto hegeliano à medida que ambos escondiam o pensamento da Voz que, ao ser revelado, mostra outro absoluto incontornável: o sacrifício humano.

O ser do ser humano é o sacrificial. O panorama da filosofia no fim do "pensamento da Voz" é marcado pelo pessimismo. O pessimismo não é, todavia, uma figura da metafísica que se pretendia superar? Vejamos como Agamben trata esse assunto, pois pretende eliminar a metafísica da Voz fundadora da morte e da negatividade, Voz que, aliás, não pode ser dita. O autor, porém, se depara então com Auschwitz, um acontecimento do ethos humano marcado por um sacrifício e abandono tão radical que tampouco pode ser dito. Esse evento é indizível pela “nossa voz”. É indizível e, pior, dele não se pode falar, sem perda da sua sublimidade negativa. A negatividade da metafísica parecia ser suprimida e enclausurada à medida que se instauraria a ética. Mas o monismo do homo sacer mantém, todavia, Agamben preso à negatividade e ao niilismo, o que lhe é oportuno, especialmente quando o assunto é o holocausto. 


\section{Um interlúdio político: Auschwitz revisitado}

Aquele que olha o fundo de um abismo tem a sensação de que o abismo olha para ele.

Nietzsche

Agamben procura tematizar Auschwitz a partir do âmbito político tornado metafísico. $\mathrm{Ou}$ seja, diferentemente de Heidegger, ele não parte do questionamento da metafísica para a política. Sua pergunta é pelo ser do político e não pelo ser dos entes. Por vezes, porém, o questionamento do político leva-o a indagar sobre suas bases metafísicas, mas essa é a parte mais deficiente dos seus escritos. Sua contribuição está em chamar a atenção sobre os limites da terminologia ética e política para a interpretação de Auschwitz como o estado de exceção mais radical e, portanto, como a desmedida de todos os males da civilização, ou melhor, como o resultado inevitável da lógica interna dessa civilização, pois se trata do "local em que se realizou a mais absoluta conditio inhumana que se tenha dado sobre a terra". 7 Acontece que com o campo de concentração a terminologia ética, demasiado vinculada à jurídica, tornou-se incapaz de dar conta desse acontecimento tão singular que escapa até mesmo à denominação estética de "tragédia". Seria algo como o oposto ou o antípoda à teologia negativa que reencontra Deus no vazio do nada, pois, nesse caso, trata-se também do "inominável" e "indizível”, isto é, de uma maldade de tal ordem que mesmo testemunhada por alguns não pode ser comunicada. Ou seja, assim como na experiência mística a beatitude divina não pode ser comunicada, a experiência de Auschwitz, como a maldade radical, tampouco o pode. Assim como os escritos de Eckhard ou Tauler podem apenas dar indícios de Deus, também os relatos dos sobreviventes são apenas indícios da maldade suprema. É como uma descida em instâncias de um inferno que nem Dante poderia expressar.

Para esboçar uma explicação do fosso que se tornou Auschwitz, Agamben tem de recorrer a outras fontes que as clássicas do pensamento político. Com isso, passando estranhamente à margem de Rawls e Habermas, se reconhece influenciado por Hannah Arendt, Walter Benjamin e principalmente por Michel Foucault, que teria anunciado que o poder político moderno não mais se preocupa com as fronteiras territoriais, mas principalmente com a segurança da população, isto é, tem como objetivo o controle da vida dos cidadãos. Trata-se, portanto, do poder que basicamente visa assegurar as condições para a reprodução da vida física. Seguindo essa indicação, Agamben, já em Homo Sacer, partia da distinção aristotélica entre vida teórica (ßíos 


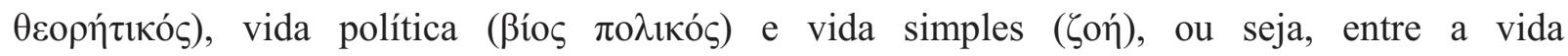
contemplativa, a vida política e civilizada e a simples vida nua. A palavra zoé diz respeito ao simples viver dos homens, animais e plantas, embora também ela se refira aos deuses. No entanto, o que é mais digno de ser vivido é a vida teórica, depois a vida política e, por último, a simples vida natural. Trata-se do cosmos hierarquizado que também se aplica ao homem, pois a vida contemplativa dos filósofos é muito superior à vida política, mas esta é superior à vida

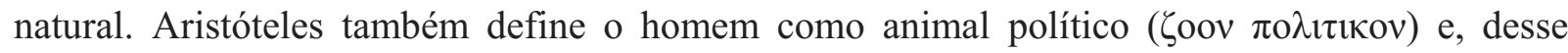
modo, o define como aquele ser que fala, que discursa e que, portanto, sendo capaz de lidar com a linguagem, debate sobre a justiça e a injustiça, o bem e o mal, e assim se preocupa com os fins da cidade e não apenas com o prazer e a dor físicos. A maior parte dos homens, porém, em meio

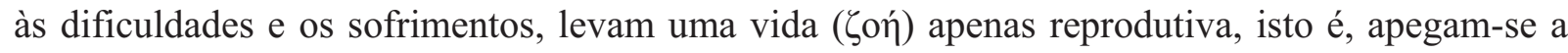
essa vida como se houvesse nela certa "serenidade e doçura natural" (Política, 1278b, 23-31). Ou seja, no cosmos hierarquizado aristotélico, mesmo excluída da vida filosófica e da vida política, na forma mais simples e natural de viver há algum bem ou dignidade. Ela não é uma vida totalmente destituída de forma e de bem, embora nada tenha a ver com a vida política, que é uma vida que pressupõe o exercício do discurso e, portanto, da linguagem. Nesse caso, a soberania estava na assembléia popular. Nos dias de hoje, porém, a vida política deu lugar a biopolítica, isto é, na vida nua é que se mostra a soberania do poder atual. A vida natural que havia sido excluída da cidade clássica torna-se, para Agamben seguindo Foucault, o centro da política moderna. Ao assegurar a existência das populações, a vida política torna-se biopolítica. Em suma, "a vida biológica como tal ocupa progressivamente o centro da vida política do homem moderno". ${ }^{8}$ Ora, isso significa que a modernidade originou uma nova concepção de soberania. Sempre teria sido assim, só que com distintas imagens do mundo. A imagem atual da soberania é a biopolítica. Trata-se de uma soberania que põe as regras do viver, mas porque dispõe da vida. E como dispõe da vida é senhora também da morte.

Nesse sentido, a vida nua, matável, está incluída na soberania exatamente porque está dela excluída. O seu caráter exclusivo é o que mostra a face do poder atual como soberania de caráter biopolítico, ou seja, a existência do homem que era vinculada à vida política se transformou em pura e simples reprodução da vida, ou melhor, ser homem é levar uma vida de ser vivente. Mas, precisamente por isso, ele reavivou a antiga imagem do homo sacer, o homem sacro, o homem que tem a vida disponível, ou melhor, uma vida totalmente posta a nu à soberania, isto é, o 
homem matável, aquele homem que pode ser morto sem que seu assassino seja responsabilizado. Ao invés do super-homem nietzscheano, o que tem, portanto, é um sub-homem. Nesse sentido, a biopolítica é o modo atual da soberania, diante da qual todos nos tornamos matáveis. Ora, se isso é assim, então quer dizer que continuamos vivendo sob a violência originária do estado de exceção. Ou seja, os códigos jurídicos atuais das sociedades ditas livres e democráticas mantêmse no caráter paradoxal da soberania, pois a tentativa de coibir a transgressão às liberdades só é possível pela persistência e a continuidade da violência que os originou. E assim, a força da lei depende do estado de exceção que a instituiu. Vejamos mais de perto como Agamben expõe esse paradoxo da soberania atual.

\section{O estado de exceção}

Segundo Agamben, o homem atual vive sob o estado de exceção. O que vem a ser isso? Exceção quer dizer eventos ou acontecimentos que se dariam fora das regras ou normas jurídicas. Acontece que tais normas não se criaram a si mesmas, mas foram instituídas num gesto de soberania, isto é, na eclosão da violência originária. Benjamin já dizia que não há nada na civilização que não tenha um fundo de barbárie. E é isso que norteia o pensamento de Agamben, para ele, a violência originária não se cessou com a lei, mas, ao contrário, continua com ela. E aqui segue Derrida, para quem toda a lei é expressão de uma violência que a instituiu. Essas considerações, porém, já se encontravam nos gregos e, nos tempos atuais, principalmente em Karl Schmitt. Os gregos, já nos poemas de Píndaro, expressavam a conexão entre violência e justiça. Muito diferentemente de Aristóteles, aliás, em Píndaro, “o poder que opera com a mão mais forte" já é indicativo disso, pois "o nomos soberano é o princípio que, conjugando direito e violência, arrisca-os na indistinção" (AGAMBEN, 2007, p. 38). Nesse caso, justiça, direito e violência são o mesmo. Nesse sentido, o monismo parmenidiano entre justiça, verdade, ser e pensamento é colocado nos termos de outro monismo, mais simples e dinâmico, e que indistintamente vincula justiça e violência.

Mas a melhor formulação desse tema foi a de um dos ideólogos do autoritarismo que concebe o poder político na forma de um paradoxo da soberania, isto é, o soberano está ao mesmo tempo dentro e fora do ordenamento jurídico. Ou seja, aquele que institui (de fora) a regra jurídica é também a fonte de validade (interna) da mesma regra. Ou seja, o soberano não só tem o 
poder de fazer valer a lei, mas também de suspendê-la. O que é ter esse poder senão deter o princípio da decisão, pois é isso que leva a instituição da lei como a sua suspensão. A decisão, porém, não depende de nenhuma regra moral ou ideia universal, ao contrário, como o ser-aí heideggeriano, o que caracteriza o soberano é a situação. O estar-em-situação é um não depender de nenhuma lei ou regra exceto aquela que ele próprio institui. Ora, posto nestes termos, o que se tem permanentemente, nesse caso, é um estado de exceção. A execução da lei depende da situação de um poder soberano que a mantém ou a elimina. E assim, nesse paradoxo da soberania, é uma ilusão supor que a lei possa retroagir e civilizar aquilo que lhe deu origem. A lei está em suspensão. Não pode ser entendida em termos gerias, pois depende do estado de exceção que a instituiu. Desse modo, segundo Schmitt, a exceção é mais interessante do que o caso normal. Este último, porém, nada prova enquanto que a exceção prova tudo; ela não só confirma a regra: a regra mesma vive só de exceção”. Karl Schmitt teria invocado aqui Kierkegaard para quem a universalização era o esvaziamento do caráter singular e pessoal da fé. A universalização é, portanto, superficialização. E se para o teólogo cristão ela era uma perda da vivência da fé, para o jurista do nacional-socialismo, ela era a perda do mais importante no mundo políticojurídico, o estado de exceção. Por isso, ele acrescenta:

Lá pelas tantas ficaremos enfadados com o eterno lugar comum do geral: existem as exceções. Se não podem ser explicadas, nem mesmo o geral pode ser explicado. Habitualmente não nos apercebemos da dificuldade, pois se pensa no geral não com paixão, mas com tranquila superficialidade. A exceção ao contrário pensa o geral com enérgica passionalidade (AGAMBEN, 2007, p. 24).

À primeira vista, é surpreendente que Agamben tenha recorrido a um dos ideólogos de soberania que levou ao estado de exceção a sua realização mais radical. Somos tentados a indagar se não seria o enfado da humanidade européia atual o que o levou a aproximar-se de Schmitt. Mas é mais do que isso, pois, visando completar as pesquisas de Foucault em História da loucura e Vigiar e punir, ele explicitamente reconhece que

uma das teses da presente investigação é a de que o próprio estado de exceção, como estrutura política fundamental, em nosso tempo, emerge sempre mais ao primeiro plano e tende, por fim, a tornar-se regra. Quando nosso tempo procurou dar uma localização visível permanente a este ilocalizável, o resultado foi o campo de concentração. 
Ou seja, não é nos hospícios ou nas prisões, mas no campo de concentração que pode-se apanhar indícios de uma soberania que, em situação de máxima radicalidade, extravasou todo ordenamento jurídico dito normal (AGAMBEN, 2007, p. 27). É, enfim, o momento da nudeza completa do homem sacro.

Para justificar sua tese central, Agamben avança apoiando-se em autores mais contemporâneos, como Alain Badiou e Jean-Luc Nancy. O primeiro fez uma interpretação política da teoria dos conjuntos precisamente recorrendo às noções de inclusão e pertencimento. Como propõe a teoria dos conjuntos, $b \subset a$, quer dizer que $b$ é um subconjunto de $a$, ou seja, todos os elementos de $b$ estão incluídos em $a$. Mas há outro caso, expresso assim: $b \in a$, isto é, de que $b$ pertence a $a$, mas sem estar incluído nele, e vice-versa. Daí Badiou transportou a noção de pertencimento à de apresentação, e a de inclusão à de representação (reapresentação). E Badiou define então como normal um termo que é incluído e representado, como excrescência o termo que está representado, mas não apresentado, e por singular o termo que está apresentado, mas não representado, ou seja, que pertence, mas sem estar incluído.

Imaginemos uma constituinte soberana, ela gera leis e, portanto, está incluída nestas, esse é o caso normal. Agora, imaginemos, leis que existem sem que se saiba quem as gerou, é a excrescência. E imaginemos ainda apenas a atividade do poder constituinte, esse seria o singular, pois nenhuma outra atividade poderia ser comparada com ela. Ora, essa singularidade incomparável seria um modo de conceber a soberania, pois esta se apresenta sem se incluir, ou melhor, opera como uma exceção à regra, mas de tal modo que é desaplicando-se que ela inclui o que lhe é exterior. Ou melhor: "A exceção soberana é, então, a figura em que a singularidade é representada como tal, ou seja, enquanto irrepresentável". Mas, lembra Agamben, que Badiou, como pensador rigoroso da exceção, acrescenta ainda uma quarta figura que daria conta de "uma paradoxal inclusão do pertencimento mesmo". Essa figura se esboçaria a partir de uma zona que tende à indistinção entre a excrescência (representação sem apresentação) e a singularidade (apresentação sem representação). Essa zona, aliás, diz respeito ao "evento", isto é, a uma situação originária em que tudo é decidido, exceto ela própria, pois seu caráter singularíssimo e hipersubjetivo é o de ser instaurador de sentido. Por isso,

ela é aquilo que não pode ser incluído no todo ao qual pertence e não pode pertencer ao conjunto ao qual está desde sempre incluída. O que emerge dessa figura-limite é a crise radical de toda a possibilidade de distinguir com clareza entre pertencimento e inclusão, 
entre o que está fora e o que está dentro, entre a exceção e a norma (AGAMBEN, 2007, p. 32).

Mas colocado nos termos do evento originário e indiscernível, abala-se a relação da soberania com a política. A noção de soberania é problematizada num limite que se torna indecidível. Isso, porém, não ocorre pela emergência de um outro conceito, isto é, a noção de soberania tornar-se-ia totalmente enclausurada se, modernamente, não acabasse incluindo por exclusão um conceito ainda mais elementar: a vida.

Ou seja, em sua radicalidade o paradoxo da soberania remete-a para além do simplesmente político e jurídico, pois essencialmente ela não é nem uma potência externa ao direito (Schmitt), nem tampouco a norma suprema do ordenamento jurídico (Kelsen), mas algo ainda mais originário; ou melhor, "ela é a estrutura originária na qual o direito se refere à vida e a inclui através da própria suspensão". E é aqui que Agamben também recorre a J-L Nancy à medida que este sugere a noção de "bando", um termo que provém do alemão antigo e que, mais uma vez diz respeito ao paradoxo, pois significa tanto a exclusão de alguém da sua comunidade quanto o poder soberano, isto é, em nome da lei é que o poder soberano bane ou abandona, coloca fora da lei. É, portanto, excluindo da lei que se aplica a lei. Com isso, a rigor não há nem inclusão nem exclusão. Nancy teria, então, expresso a estrutura ontológica da lei nos termos do abandono, isto é, se para Heidegger a história do pensamento metafísico ocidental é colocada nos termos da indigência do pensar e, portanto, de que o ente foi abandonado pelo seer (Seyn), para Nancy, trata-se de pensar a soberania pela qual somos abandonados. No abandono revela-se o poder total da lei que gera os fora da lei. Mas, em relação a quem se é abandonado senão ao bando soberano? E o que, em última instância, é abandonado senão a vida? No abandono, o bando soberano revela uma vida sem-lei, a vida posta totalmente a nu. No abandono, a vida está simplesmente disponível e, por isso mesmo, é matável.

Nas palavras de Nancy:

Abandonar é remeter, confiar ou entregar a um poder soberano, confiar ou entregar ao
seu bando, isto é, à sua proclamação, à sua convocação e à sua sentença. Abandona-se
sempre a uma lei. A privação do ser abandonado mede-se com o rigor sem limites da lei
à qual se encontra exposto. O abandono não constitui uma intimação a comparecer sob
esta ou aquela imputação da lei. É constrangimento a comparecer absolutamente diante
da lei, diante da lei como tal na totalidade. Do mesmo modo, ser banido não significa
estar submetido a uma certa disposição de lei, mas estar submetido à lei como um todo.
Entregue ao absoluto da lei como um todo. Entregue ao absoluto da lei, o banido é 
também abandonado fora de qualquer jurisdição [...]. O abandono respeita a lei, não pode fazer de outro modo. ${ }^{9}$

Ora, sem nenhum direito, ao abandonado resta apenas a vida, uma vida, aliás, sem valor, pois este dependeria de uma ética que, por sua vez, é concebida dentro da jurisdição do bando soberano. E assim a relação do bando soberano com o abandonado é o estado de exceção em que se confundem a violência e o direito, como atualmente se encontra, por exemplo, no aborto, na eutanásia, na morte dos fetos anencéfalos. Os pacientes terminais, em estado de coma profundo ou com morte cerebral, são amostras da sujeição e do abandono do homem face ao estado de exceção biopolítico. Mas a figura que melhor expressa a vida radicalmente posta a nu e abandonada é a do homo sacer. A origem dessa figura jurídica, porém, não é moderna. Agamben afasta-se aqui de Foucault e Arendt para retomar essa noção tal como se encontrava no antigo direito romano.

\section{Homo sacer}

Em sua origem a noção de homo sacer é enigmática. Ela provém do direito romano arcaico e dizia respeito a mais antiga pena criminal. Sua estranheza, porém, deve-se a uma (aparente) contradição, isto é, no trecho que sobreviveu há um breve enunciado que parece negar o que é afirmado na enunciação geral. Essa enunciação se encontra na obra de Sexto Pompeu Festo Sobre o significado das palavras. E ela diz o seguinte:

\footnotetext{
O homem sacro é, portanto, aquele que o povo julgou por um delito; e não é lícito sacrificá-lo, mas quem o mata não será condenado por homicídio; na verdade, na primeira lei tribunícia se adverte que 'se alguém matar aquele que por plebiscito é sacro, não será considerado homicida'. Disso advém que um homem malvado ou impuro costuma ser chamado sacro. (AGAMBEN, 2007, p. 79).
}

A contradição é óbvia, pois ao mesmo tempo em que se fala da sacralidade de um homem, também autoriza-se a sua morte. Mas isso com algumas nuanças, pois o homem sacro pode ser morto por qualquer um sem recorrer-se às formas tradicionais do rito sagrado. O homem sacro é, portanto, aquele que pode ser morto sem os ritos do sacrifício. É como se a linguagem ritualística fosse suspensa e ele se tornasse apenas um corpo neutro, destituído de sentido e, por isso, simplesmente matável. Ou seja, ele se situa à margem dos deuses e dos homens. Ora, segundo o ordenamento jurídico romano, o homem sacro ficaria à margem tanto da justiça divina quanto da ethic@- Florianópolis v. 11, n. 3, p. 329 -354, Dez. 2012. 
humana. E, mesmo nas interpretações mais díspares como a de Ward W. Fowler, para quem o homem sacro era impuro, como a de Károly Kerényi, para quem ele era propriedade dos deuses, há uma questão de fundo que não está esclarecida. O que, portanto, interessa a Agamben é questionar essa especificidade do homem sacro que reside na "impunidade da sua morte e no veto do sacrifício". E a questão é: por que qualquer podia matá-lo sem ferir a lei dos homens e a dos deuses? Que vida é essa do homo sacer levada a cabo à margem tanto do ordenamento jurídico humano quanto do divino? Ora, está-se aí, portanto, lidando com um conceito limite cuja compreensão, segundo Agamben, levaria para além da etnologia, antropologia e do direito, pois, essa ambiguidade originária da sacratio permitiria "lançar uma luz sobre uma estrutura política originária, que tem seu lugar em uma zona que precede a distinção entre sacro e profano, religioso e jurídico" (Agamben, 2007, p. 81).

Essa luz, porém, só poderia iluminar algo aqui se se afastasse o mitologema cientificista que, desde o século XIX, paira sobre a antropologia. Como Wittgenstein que denunciara a metodologia cientificista de Frazer na interpretação dos povos primitivos, também essa mesma raiz vitoriana que via a experiência sagrada dos primitivos com repugnância e horror, se estende por tudo a ponto de perder de vista a genuína experiência ocidental do sagrado, isto é, seus preconceitos cientificistas desviam-na do ponto originário em que se tocam o sacro e o profano, a santidade e impureza, e, desse modo, perde-se a mescla de veneração e horror em que define o homem sacro. O que interessa a Agamben é, portanto, indo para trás da separação moderna entre o sacro e o profano, tentar recuperar a sua ambivalência originária e que, como se viu, se encontra, segundo ele, na supracitada passagem do direito romano antigo. Aí a ambivalência, colocada em termos jurídicos, caracteriza a sacralidade como a imunidade da matança e a exclusão do sacrifício. Isto é, o homem sacro está fora tanto do âmbito humano quanto do divino. E temos aí, então, a ambivalência ou até mesmo o paradoxo que levam Agamben a algumas passagens mais esclarecedoras:

1. “A vida sacrificável e, todavia, matável, é a vida sacra;

2. soberana é a esfera na qual se pode matar sem cometer homicídio e sem celebrar um sacrifício, e sacra, isto é, matável e insacrificável, é a vida que foi capturada nesta esfera; 3. a sacralidade da vida, que se desejaria hoje fazer valer contra o poder soberano como um direito humano em todos os sentidos fundamental, exprime, ao contrário, em sua origem, justamente a sujeição da vida a um poder de morte, a sua irreparável exposição na relação de abandono" (AGAMBEN, 2007, p. 90-91). 
Como se vê, o pós-cristão Agamben entende como sagrado precisamente o que é matável, o que, enfim, foi abandonado pelos deuses e pelos homens. Ora, qual foi a maior expressão dessa condição senão os campos de concentração? Foi neles que se mostrou a mais radical relação de abandono e onde a vida, desnudada pelo poder soberano, mostrou o seu caráter totalmente matável, isto é, o campo de concentração foi o espaço biopolítico em que a vida ficou totalmente exposta ao bando soberano. Foi nesse espaço que, aliás, se mostrou que a soberania atual, enquanto biopolítica, promove a vida para matá-la. O que o cristianismo, o iluminismo e o liberalismo tentaram esconder revelou-se em Auschwitz com toda a clareza: a soberania biopolítica é, portanto, a última e mais radical dessacralização do mundo, pois a própria noção de sacro equivale não apenas a ser abandonado pelos deuses, mas pelo homem também. Ou seja, entregue ao bando soberano biopolítico revelou-se a essência do homo sacer. Sua essência, porém, não tem a dignidade do bíos, mas a indignidade da pura e simples zoé, isto é, o poder que governa esse sub-homem é, portanto, essencialmente pagão e inumano. Ao invés do superhomem, no campo de concentração, revelou-se o sub-homem. Ou seja, ao revelar o sub-homem, revelou também o poder soberano, pois sendo o estatuto originário o bando é precisamente este que mantêm unidos tanto a vida nua quanto o poder soberano. O que é um bando senão que vive num estado de abandono e, portanto, que está à mercê ou sob o domínio de. Ora, só se está abandonado pelo bando, pois "o bando é propriamente a força, simultaneamente atrativa e repulsiva, que liga os dois pólos da exceção soberana: a vida nua e o poder, o homo sacer e o soberano" (AGAMBEN, 2007, p. 117). E assim é na vida nua exposta na situação de maior abandono que se revela a soberania da biopolítica que, no nazismo, partiu não só para experiências as mais bizarras possíveis até o programa de extermínio total dos judeus: a solução final.

Ora, um programa de extermínio não é feito sem regras. Daí porque no estado de exceção o campo de concentração é o modo mais radical de exercício de poder soberano, isto é, a instância espaço-temporal que se mostra, na norma, a violência da soberania originária. $\mathrm{O}$ estado de exceção já não é algo externo, mas passa a se confundir com a norma. O campo surge quando o estado de exceção tornou-se regra. Mas isso é possível porque o que se revela no campo, em sua radicalidade, é barbárie que funda e sustenta a lei. No campo de concentração mostra-se o que geralmente está oculto nas legislações democráticas ou não, isto é, o "campo é o sinal da impossibilidade do sistema funcionar sem transformar-se em uma máquina letal" (AGAMBEN, 
2007, p. 182). E assim, na modernidade atual a cidade foi substituída pelo campo de concentração, é este o paradigma biopolítico em que se consolidou o homem sacro. A eutanásia, a morte cerebral, o aborto, etc. são exemplos menores desse modelo. Desse modo, um tal monismo biopolítico posto em termos heideggerianos é o dispositivo de destruição da vida que determina os homens de tal modo que todos se tornam homens sacros, pois, abandonados a ele, postos a sua mercê, verdugos e torturados, assassinos e assassinados não fazem mais que reproduzi-lo. Ou seja, esse dispositivo que inclui excluindo faz viver apenas para matar.

Mas, segundo Agamben, a mais desenvolvida expressão da biopolítica foi o campo de concentração nazista onde foram realizadas as mais mirabolantes experiências com cobaias humanas. Mas o pesadelo do holocausto, muito além da imaginação dantesca, revelou novos âmbitos do inferno desconhecidas para o homem sacro clássico. Trata-se da figura do "muçulmano", recuperada por Primo Levi em seus livros. O jargão "muçulmano" foi empregado nos campos primeiro pelos alemães e depois pelos próprios judeus para se referirem aos prisioneiros que tiveram suas vidas totalmente expostas e desnudadas pelo bando soberano, isto é, são aqueles que, na radical situação de abandono, haviam descido mais abaixo da humilhação, do horror e do medo e estavam reduzidos a mais completa apatia e indiferença. Isto é, a figura do muçulmano nada mais tem a ver com a bios, mas trata-se da pura zoé. O muçulmano, portanto, move-se numa zona em que já não é mais possível distinguir entre fato e direito, vida e norma, natureza e política. A separação entre a vida e a morte reduziu-se praticamente a nada. Sua aniquilação era de tal ordem que inclusive deixaram de habitar a zona de perigo. O muçulmano é a experiência mais radical da sub-humanidade. Tentemos ver melhor essa figura, pois para Agamben ela representa precisamente o fundo do modelo biopolítico em que se enraíza o homem atual.

\section{O muçulmano}

A melhor expressão do homem sacro, isto é, daquele insacrificável e, por isso mesmo, matável, foi precisamente aquele que na experiência do horror do holocausto chegou ao ponto de maior desnudamento e impotência frente ao poder soberano. Mais do que em qualquer outra, é na figura do muçulmano que, como mais radical experiência do abandono, mostra-se o estado de exceção que se torna regra, ou melhor, mostra-se a zona cinzenta do poder na indistinção entre a 
violência e o direito. A figura do muçulmano é o indício do mal radical enquanto biopolítica. Ele não é, porém, uma especulação filosófica, mas uma realidade histórica cuja experiência, para Agamben, sequer pode ser formulada com o vocabulário ético tradicional. Portanto, diante dessa dificuldade seria fácil passá-lo por alto se não existissem testemunhas. Mas como é possível testemunhar a condição do muçulmano sem ser inverossímil? Como é possível descrever um evento das proporções de Auschwitz? Que linguagem poderia descrever o indescritível? No entanto, esse evento singularíssimo na "história universal da infâmia" (J. L. Borges) foi testemunhado. As testemunhas são, obviamente, aqueles que de um modo ou de outro, passaram pela experiência do campo, isto é, aqueles que sobreviveram para vingar-se contando a história. O importante aqui é que a testemunha não é alguém que olha de fora e que, portanto, teria certa neutralidade em relação ao ocorrido. Para Agamben, o testemunho só é válido porque aquele que relata é o mesmo quem viveu essa experiência. $\mathrm{O}$ testemunho de um acontecimento tão grandioso em maldade e violência, porém, rompe com as categorias jurídicas e éticas.

O principal testemunho é o de Primo Levi. Ele sobreviveu a Auschwitz para testemunhar, ou melhor, ele só tornou-se escritor para relatar esses acontecimentos. Aliás, foi a decisão de escrever sobre as suas experiências no campo de concentração que lhe deu um sentido para viver, isto é, para superar a culpa de não haver lutado e de ter sobrevivido em meio a tantos que haviam morrido nas condições mais ignóbeis. E foram os "muçulmanos" dos campos de concentração que mergulharam mais fundo na ignomínia. O muçulmano é aquele que, entre os outros prisioneiros sofre a experiência mais radical de abandono. Ele não foi apenas largado de mão pelos donos do poder, mas pelos próprios companheiros, isto é, pelos próprios judeus que os olhavam com desprezo e os evitavam como se estivessem com peste. Primo Levi lembra que “quando descíamos aos banheiros, fizeram descer conosco um grupo de 'Muselman', como haveríamos de chamá-los depois, que eram os homens-múmia, os mortos-vivos; e os fizeram descer conosco unicamente para que víssemos, como se dissessem: vocês ficarão iguais". E Levi que, como os outros prisioneiros, evitara olhar para os muçulmanos, anos depois e cheio de remorsos por ter sobrevivido evitando olhar para seus parceiros mais infelizes do campo, escreve:

\footnotetext{
Eles povoam a minha memória com sua presença sem rosto, e se eu pudesse concentrar todo o mal de nosso tempo escolheria essa imagem que me é familiar: um homem macilento, cabisbaixo, de ombros curvados, em cujo rosto, em cujo olhar, não se possa ler o menor pensamento (AGAMBEN, 2008, p. 52). ${ }^{10}$
} 
Ou seja, embora tendo os evitado, Levi olhou-os o suficiente para, como sobrevivente, recordálos muito depois. E foi esse sentimento de culpa por não haver lutado e por haver evitado olhar para seus parceiros de maior infortúnio que fez Levi escrever. Levi não escreve para se vingar dos opressores, mas para se justificar ter sobrevivido em meio aos terríveis males que padeceu seu povo. Levi escreve trespassado pelo remorso de nada ter feito. E busca no testemunho escrito uma justificação e consolação.

O muçulmano era, na descrição de J. Améry, um cadáver ou um esqueleto ambulante que perdera completamente a noção de bem e mal, justiça e injustiça, nobreza e vileza, espiritualidade e não espiritualidade. A situação de abandono muçulmano que, anos depois, Améry escreve: "Devemos, por mais dolorosa que nos pareça a escolha, excluí-lo de nossa consideração". Nesse ponto devemos concluir que Levi foi mais corajoso.

A figura do muçulmano para Agamben mostra a vida nua em sua radicalidade, isto é, de que nessa figura destituída de humanidade se expressa o poder absoluto do bando soberano. $\mathrm{O}$ muçulmano é a realização cabal da forma de poder atual em que, ao contrário do que propunha Nietzsche, reduziu o homem a sub-homem. Portanto, nessa "terra do muçulmano", da qual Levi é cartógrafo, torna-se um paradigma da maldade, pois "o muçulmano, que é a formulação mais extrema da mesma, é o guardião do umbral de uma ética, de uma forma de vida, que começa onde acaba a dignidade" (AGAMBEN, 2008, p. 76). Ora, considerando que essa "terra do muçulmano" era o porão de Auschwitz, que os prisioneiros se recusavam até mesmo olhar, só podia ser precariamente entendida como a mais inenarrável das histórias. Isto é, tudo que as memórias desse momento terrível puderam resgatar sempre serão insuficientes para dar conta do evento fundamental da história da infâmia. Esse evento é o afundamento completo da razão prática kantiana no terreno obscuro da Terra do Nunca da maldade. Mas a questão, porém, insiste em não calar: como testemunhar o que está além da compreensão humana? Em outras palavras, a natureza do muçulmano é tão insólita e estranha que seu julgamento escapa à ética e ao direito tradicional. Exigiria, portanto, uma nova abordagem da vida prática e, consequentemente, uma nova ontologia. Uma ontologia que ao invés de partir da noção heideggeriana de abandono do ser, parte da noção de que sob a soberania biopolítica os homens permanentemente estão numa situação de abandono. Mostrarei mais adiante, que Agamben não poderá deixar de algum modo, ainda que precário, de tratar desse tema abordando a linguagem, pois as palavras éticas ou políticas, antes de tudo, não podem ser compreendidas sem que se recorra à linguagem. 
O testemunho de Levi, porém, serve para Agamben colocar em questão o próprio direito que condenou os carrascos nazistas em Nuremberg e em outros processos levados a cabo na Alemanha e fora dela como o de Eichmann, em Jerusalém, no ano de 1961. Ora, por mais que esses processos tenham sido necessários eles foram insuficientes porque não só difundiram a falsa ideia de que o problema tinha sido superado, como ainda são responsáveis pela confusão das mentes que, por décadas, "impediu de pensar Auschwitz". Mas como pensar esse acontecimento? Agamben, recorrendo novamente a Primo Levi, reconhece uma "zona cinzenta" em que se misturam os algozes e as vítimas, isto é, uma zona de irresponsabilidade em que opera uma incapacidade de julgamento, ou seja, uma em que o homem foi tão destituído de dignidade que não pode mais ser julgado pelos padrões conhecidos, enfim, uma zona que expressa "a banalidade do mal que desafia as palavras e os pensamentos" (AGAMBEN, 2008, p. 31).

Mas, pelo visto, não apenas a ética é contagiada pelo direito, mas também a estética, pois, concebidas no mesmo modelo metafísico da polis, não conseguiriam expressar o acontecimento de Auschwitz, cujo testemunho estaria muito além de qualquer expressão poética ou prosaica simplesmente porque os relatos dos muçulmanos apenas apontam, ou seja, são apenas indícios, do inominável e, portanto, do incomunicável. Trata-se de uma demonologia na sua maior negatividade. O mal não é, como pensavam os clássicos, uma carência do bem: o mal está em execução a partir de si mesmo. Aqui, o evento de Auschwitz ultrapassa a capacidade estética de expressão e, com todo seu poder aniquilante, se coloca como o limite que define o fim da antiga e o começo de uma nova ontologia. As fotos e as rápidas imagens cinematográficas de Auschwitz tornam os poemas de Morgue, e até mesmo o hiperrealismo naturalista de Augusto dos Anjos, débeis expressões da vida posta em sua nudeza radical. Mas mesmo os relatos dos testemunhos, fotografias e filmes ainda não conseguem, kantianamente falando, aproximar-se desse abismo, não apenas da imaginação transcendental, mas da própria razão prática. As imagens e os conceitos não podem dar conta da singularidade desse evento da sublimidade do mal. Mas calar aqui é consentir. Por isso, tenta-se dizer o indizível.

\section{Dizer o indizível?}

Para Agamben, o grande empecilho para se pensar o evento singular do campo foi precisamente a noção de processo penal. Quem melhor expressou isso foi Franz Kafka, 
precisamente numa das suas obras mais importantes: O processo. Essa obra começa quando o personagem José K, um simples bancário que nunca fez nada de reprovável, recebe uma intimação para comparecer numa audiência num tribunal, pois precisa responder que tipo de acusação levanta-se contra ele. É uma situação absurda que Kafka imagina para revelar o sentimento de culpa do homem. O testemunho é culpa. Se em SZ, o ser-aí surge da angústia, em Kafka, o homem se mostra como essencialmente culpado. Nos dois casos, não se sabe o porquê. A angústia, na busca pelo sentido do ser, revela o ser-aí para si mesmo. Na narração do processo de José K revela-se, porém, a culpa do homem por algo que ele não sabe o que é. Ou seja, a angústia revela o ser-aí para si sem que se saiba o porquê, a culpa também revela o homem para si sem nenhum motivo ou razão. A interpretação desse assunto, em Kafka, seria muito vasta. Agamben resume-as a três alternativas:

a) a que sublinha o caráter profético-político em que se destaca a burocracia moderna como mal absoluto;

b) a teológica em que o tribunal é o Deus desconhecido;

c) a biográfica em que o tribunal é a doença de que Kafka sabia estar sofrendo.

Essas três interpretações correntes, porém, teriam passado por alto precisamente da reflexão profunda que a obra kafkiana faz sobre a natureza do direito e, portanto, da lei. Isto é, sobre a natureza do julgamento como processo que tende a absorver tudo em si, como na conhecida expressão: “o que está fora dos autos não existe”. E esse é o paradoxo do processo, pois tendo em vista um julgamento que acaba por nada julgar de fato, e assim "não pune, nem premia, nem faz justiça, nem estabelece a verdade". Daí a invocação de Kafka, pois "o julgamento é em si mesmo a finalidade, e isso - já foi dito - constitui o seu mistério, o mistério do processo". Ora, como a moral está contaminada pelo processo, a inocência e a culpa estão mergulhadas na "zona cinzenta". A maior expressão dela teria sido Auschwitz. Nas palavras de Agamben, seguindo Primo Levi: "Trata-se de uma alquimia cinzenta, incessante, na qual o bem e mal e, com eles, todos os metais da ética tradicional alcançam seu ponto de fusão" (AGAMBEN, 2008, p. 28, 30). Ou seja, não é possível julgar porque tampouco é possível compreender o que se julga. As palavras tradicionais já operam aqui. Como testemunhar o que não se pode compreender? Como compreender o que, a rigor, não se pode testemunhar? Diante de Auschwitz, as palavras da tradição ética e jurídica, como razão, bondade, justiça, perdão, esperança, equidade, responsabilidade, bem, mal, verdade, piedade, amor etc., caem no vazio. 
Ora, a discussão do que é dizível ou não, envolve não apenas as palavras da ética ou do direito, mas se estende até a linguagem mesma. Agamben recorre aqui, a meu ver, de modo efêmero e de passagem, a Saussure, Benveniste e a vários poetas, cuja análise mais detalhada me levaria muito longe. Tentemos ficar, portanto, nas suas referências a Heidegger que, como já salientei, é um dos filósofos que mais influenciaram esse autor, pois em seu projeto de superar a metafísica estava também embutida a superação da ética tradicional.

Uma das dificuldades das palavras tradicionais dar conta do "evento do campo" é precisamente a morte, pois o que lá aconteceu foi um sequestro da morte, isto é, numa forma radical, retirou-se dos prisioneiros a dignidade da morte. As vítimas do campo estavam condenadas não a morrer, mas a perecer; rilkeanamente falando, tratava-se de "mortes abortadas" em que os "cadáveres eram jogados fora como esterco" etc. Em 1949, nas Conferências de Bremen, Heidegger, associando a morte à técnica, reconhece:

\footnotetext{
Morrem? Perecem. São eliminados. Morrem? Convertem-se em peças de armazém de fabricação de cadáveres. Morrem? São liquidados imperceptivelmente nos campos de extermínio. Mas morrer (Sterben) significa suportar a morte no próprio ser. Poder morrer significa: encarar tal decidida suportação. E nós o podemos unicamente se o nosso ser pode o ser da morte [...] Por todos os lados, a imensa miséria de inumeráveis, atrozes mortes não morridas (ungestorbener Tode), contudo a essência da morte está vedada ao homem. $^{11}$
}

Heidegger, nessa passagem vincula a morte à técnica, mas ainda invocando o problema da morte a partir do ser-aí e, portanto, de que o fenômeno da morte está vedado ao homem, isto é, que ele diria, então, respeito à abertura originária de onde surgem homens e deuses. Mas Agamben, associando-a apenas aos cadáveres, dos que perecem de modo trivial e burocrático, perde de vista aqui precisamente a essência do morrer. Seja como for, para ele, é essa trivialidade da morte no campo que escapa às categorias éticas e jurídicas. Ora, se tais categorias são incapazes de descrever a situação do muçulmano e da sua eliminação, então isso se estenderia a toda a linguagem. Como, porém, conciliar o testemunho com a linguagem em que ele expressa seu testemunho? Pois, mesmo que o testemunho se depare com o indizível ou procure falar por quem já não pode mais fazê-lo, o testemunho é o sujeito de um enunciado, mas, então, aqui Agamben se vê em grandes apuros, pois, e nas palavras de Foucault, a que ele mesmo recorre, “como pode a liberdade de um sujeito inserir-se nas regras de uma língua?" E, então, o "aluno de Heidegger”, recupera aquilo que o filósofo sempre objetou: a noção de sujeito. E mais: é no sujeito que se dá ou não a possibilidade de se exercitar ou não uma língua. "O homem é o falante ethic@-Florianópolis v. 11, n. 3, p. 329 -354, Dez. 2012. 
que tem a linguagem porque pode não ter a língua [...] Este dar-se encontra, na língua, a forma de uma subjetividade. A contingência é possível posto à prova de um sujeito". Ora, essa subjetividade é que permite que o testemunho tenha na possibilidade falar uma impossibilidade da palavra. Ou seja, aquilo que era atribuído à impossibilidade das palavras da tradição é agora entendido desde um sujeito que, enquanto tendo a possibilidade de falar, não consegue fazê-lo, pois "o testemunho é uma potência que adquire realidade mediante uma impotência de dizer e uma impossibilidade de falar" (AGAMBEN, 2008, p. 147). Agamben dá-se conta que está aqui usando e abusando das categorias modais da tradição ontoteológica da metafísica como possibilidade, impossibilidade, necessidade, contingência etc. E ao invés de criticá-las como o que torna indizível o testemunho nos padrões da tradição, ele faz precisamente o contrário, e as assume com a maior naturalidade; pois mesmo reconhecendo que elas se antecipam às palavras ético-jurídicas à medida que

\begin{abstract}
não são categorias lógicas ou gnosiológicas inócuas, que têm a ver com a estrutura das proposições ou com a relação a algo da nossa faculdade de conhecer. Elas são operadores lógicos, isto é, as armas devastadoras com que se combate a gigantomaquia biopolítica pelo ser, e se decide, de cada vez, sobre o humano e sobre o inumano, sobre um 'fazer viver' ou um 'deixar morrer'. O campo de luta é a subjetividade. (AGAMBEN, 2008, p. 148).
\end{abstract}

E, mesmo tendo à disposição Wittgenstein, Habermas, Apel etc., ele entende a subjetividade nos termos de "um mundo que é sempre meu mundo" ou de "um mundo que nunca é meu mundo, pois nele a possibilidade não existe" (AGAMBEN, 2008, p. 148). Isto é, para esse autor, a subjetividade, colocada nos termos dos operadores ontológicos é o que permite que em um sujeito se possa tratar do que pode ou não ser dito, do ele pode ou não pode e, portanto, decide também sobre a relação entre a testemunha e o muçulmano. Pelo visto, a tentativa de Agamben de pensar fora das categorias tradicionais acaba mergulhando novamente nos problemas metafísicos que Heidegger objetou extensamente. Ou seja, como o testemunho pode dar conta do indizível se o "campo de luta é a subjetividade"? Não seria precisamente no modelo metafísico da subjetividade que se gerou o evento terrível sobre o qual suas categorias ontológicas já não podem dar conta? Esse apelo à subjetividade e às categorias ontológicas, como a de possibilidade e contingência, já sinalizam o beco sem saída em que esse autor se meteu: o monismo biopolítico. A interpretação subjetivada das categorias ontológicas é tentativa de manter aberta a porta da 
transcendência. Porém, como tratar de assuntos ontológicos sem invocar as palavras tradicionais da filosofia? Agamben, pelo jeito, quer expulsar o diabo invocando Belzebu.

Em Homo Sacer, ele retoma ocasionalmente certos temas de seu mestre Heidegger, mas, como costume, sem explorá-los com o esmero que o assunto exige. Mostrei que Agamben emprega a noção de "bando" de J - L Nancy para mostrar que a soberania instaura efetivamente uma zona cinzenta, isto é, uma zona de abandono, pois é "a lei além da lei à qual somos abandonados"; em outras palavras, que só conseguimos pensar o ser do abandono além de toda ideia de lei. Essa zona cinzenta é também um âmbito vazio, carente de significado, pois a linguagem não pode exprimi-lo. Ora, se se conseguir tematizar esse âmbito poder-se-á também escapar do paradoxo da soberania em direção a uma política livre das relações com o bando soberano, ou seja, tematizar esse fundo é alcançar também aquilo que, ao exceder a lei, a confirma em seu vínculo com a violência originária do poder soberano, do qual a figura mais acabada é a do muçulmano pela total dissolução da bios na zoé; é, enfim, avançar para a compreensão dessa "zona de indiscernibilidade entre a lei e a vida, ou seja, um estado de exceção" (AGAMBEN, 2007, p. 66). Aqui, porém, mais uma vez, reaparece o segundo Heidegger como pano de fundo, pois se se trata de pensar uma instância em que as palavras tradicionais ficam em suspenso, então o tema dos temas é o do esquecimento do seer (Seyn), pela indigência do pensar, ou melhor, o da diluição do sentido do seer devido ao seu abandono pelo ente. Pois o "ser não é aqui outro senão o ser abandonado e remetido a si mesmo do ente, o ser não é senão o bando do ente"; nas palavras de Heidegger, no Beiträge für Philosophie:

\footnotetext{
O que é abandonado por quem? $\mathrm{O}$ ente pelo ser que lhe pertence e não pertence senão a ele. O ente surge então assim, surge como objeto e como ser disponível, como se o ser não fosse [...] Então mostra-se isto: que o ser abandone o ente significa: o ser se dissimula no ser manifesto do ente. E o próprio ser é determinado essencialmente como este dissimular-se subtraindo-se [...] Abandono do ser: quer o ser abandone o ente: que o ser abandone o ente, que este seja entregue a si mesmo e torne-se objeto da maquinação. Esta não é simplesmente uma "queda", mas é a primeira história do próprio ser (HEIDEGGER, 1989, p. 115). ${ }^{12}$
}

Mas, como se viu, a interpretação do abandono do seer é feita por Agamben nos termos da biopolítica. Sua dificuldade é, porém, a de transformar o enclausuramento do poder soberano enquanto biopolítica em um monismo também enclausurado em si. Isto é, o reino encantado da metafísica como Terra do Nunca fica imobilizado num holismo totalmente carente de transcendência. Portanto, se Heidegger mantém a noção de que a entificação se dá a partir da 
abertura originária do seer, Agamben, por seu lado, se vê numa encruzilhada. A sua saída será novamente vincular a ontologia com a escatologia, ou melhor, a ontologia grega com o soteriologia judaica. Nesse caso, acaba por fazer uma leitura pós-cristã do cristianismo. Esse feito, não está apenas ligado a Benjamin, mas também ao esforço nietzscheano e heideggeriano para pensar para além do cristianismo. Por que vincular isso com Heidegger? Logo mostrarei que, para este filósofo, a essência da maquinação é cristã, ou melhor, o Deus cristão e criador se torna ainda mais efetivo com a matemática moderna e a sua noção de infinito o que, portanto, desde Descartes, passando pelo idealismo alemão, determina a metafísica da era do niilismo.

\section{Excurso: ainda o "muçulmano"}

Imagine-se agora o habitante do campo, na sua mais extrema figura. Primo Levi descreveu aquele que, no jargão do campo, era chamado "o muçulmano", um ser em que a humilhação, horror e medo haviam ceifado toda a consciência e toda a personalidade, até a mais absoluta apatia (daí sua irônica denominação). ${ }^{13}$

Mas se Auschwitz não pode ser esquecido como uma efetiva manifestação do mal radical, tampouco pode ser usado para encobrimento dos crimes contra a humanidade feitos pelo bando soberano sionista. "Auschwitz", portanto, não são apenas narrativas verbais, mas o poder das imagens na era da comunicação. Com Auschwitz, a angústia do ser-aí é uma tonalidade afetiva demasiado tíbia, e mais, mesmo o temor filosófico frente ao abismo do fim da metafísica transforma-se em terror de um estado de exceção em sua radicalidade máxima. São imagens inscritíveis, (indescritíveis) por certo, mas que também servem para bloquear as objeções ao terrorismo atual contra os "muçulmanos". Numa entrevista, Jimmy Carter, antes da "batalha" de Gaza, afirmou que, devido ao longo cerco israelense, os jovens da Faixa de Gaza estavam se tornando uma geração de nanicos. É a atual biopolítica do terror. Até que ponto "atual" não quer dizer "tradicional", pois o banditismo israelense de hoje continua uma prática antiga. Nesse sentido, poder-se-ia aqui invocar Robertson Smith citado por Agamben:

Uma outra notável herança hebraica é o bando (herem), com o qual um pecador ímpio, ou então inimigos da comunidade e do seu Deus, eram votados a uma total destruição. $\mathrm{O}$ bando é uma forma de consagração à divindade, e é por isto que o verbo 'banir' é às vezes vertido como 'consagrar' (Miq. 4.13) ou 'votar' (Lev. 27-28). Nos tempos mais antigos do hebraísmo, ele implicava, porém, a completa destruição não somente da pessoa, mas das suas propriedades [...] somente os metais, depois de terem sido fundidos 


\begin{abstract}
ao fogo, podiam ser incorporados no tesouro do santuário (Jos. 6-24). Mesmo o animal (bestiame) não era sacrificado, mas simplesmente morto, e a cidade consagrada não devia ser reconstruída (Dt. 13-16; Js 6-26). Um tal bando é um tabu, tornado efetivo por um temor de penas sobrenaturais (RS., 16-34) e, como tabu, o perigo nele implícito era contagioso (Dt 7.26); quem porta à sua casa uma coisa consagrada incorre no mesmo bando. $^{14}$
\end{abstract}

Agamben poderia ter aqui reconhecido também a atual política israelense de destruição aliada à de elevação dos muros de segregação étnica e religiosa, dos assassinatos seletivos ou massivos. Sobre esse tema, aliás, o silêncio de Agamben (como de Habermas) em seus livros mais conhecidos não é só um sinal da cumplicidade, mas de adesão, não ao que diz respeito aos muçulmanos, e sim às táticas judaizantes que, como logo mostraremos, fazem parte das leituras pós-cristãs do cristianismo. ${ }^{15}$

Traumatizado por Auschwitz, Primo Levi, como vimos, não hesita em julgar seus algozes e desejar vingança; confessa que não tem mais autoridade para perdoar, como se o perdão precisasse de autorização. Reconhece que, no campo de concentração, "vítima e carrasco são igualmente ignóbeis; a lição dos campos é a fraternidade da abjeção", mas também seu desejo de justiça é implacável, isto é, se os nazis cometeram um crime devem pagar: "Se tivesse tido diante de mim um Eichmann, o teria condenado à morte" (AGAMBEN, 2008, p. 27). Israel condenou Eichmann à morte, mas sua violência originária persistiu, pois também foram as razões de Estado que, cada vez com maior poderio bélico do bando soberano, desnudou e tornou matável os palestinos, ou seja, os genuínos "muçulmanos" ipsis literis, os muçulmanos que praticavam a religião islâmica e que viviam na Palestina e lá, com o seu constante alijamento pelos sionistas que chegavam para invadir suas terras, deram origem a expressão pejorativa empregada nos campos. Portanto, a origem da expressão "muçulmano" - curiosa ou astutamente não estudada por Agamben - está já na ocupação sionista de Palestina. ${ }^{16}$ Pelo jeito, Agamben não consultou as memórias do sionista Hans Jonas, que, mesmo peremptoriamente já mostra como nos anos vinte havia conflitos cada vez mais violentos entre os sionistas e os "muçulmanos", criadores de carneiros, pequenos agricultores que viram suas terras serem ocupadas por gente de fora. Essa gente eram os sionistas, muitos formados em Universidade ou praticantes do judaísmo que olhavam com desprezo o analfabetismo e o atraso dos "muçulmanos" palestinenses; e assim, gente que como Jonas - que mais tarde não perdoariam o nazismo de Heidegger - alimentavam sonhos de glória militar. No caso desse autor, esses sonhos tinham, no começo, a Alemanha como 
cenário, mas devido à dificuldade do empreendimento, mudaram-no para o Oriente Médio. Em suas Memórias Hans Jonas diz:

\begin{abstract}
Quando começou a despertar-se meu sionismo, imediatamente ficou claro para mim que esta estratégia era, no melhor dos casos, uma coisa passageira e que o verdadeiramente necessário era emigrar para a Palestina. Imaginava-me indo à cabeça de um exército judeu armado, instruído em diferentes países do galut (exílio), que marchava pela terra de uma Europa hostil através do Bósforo, pela Ásia Menor até a Palestina. ${ }^{17}$
\end{abstract}

E, embora Jonas não desenvolva especificamente o termo "muçulmano", sua descrição de como o sionismo foi ocupando militar e culturalmente esse território, é um indicativo de como surgiu, na sua comunidade mais ilustrada, o termo depreciativo que depois foi transportado para a Europa e usado nos campos de concentração.

É, portanto, muito estranho, para não dizer comprometedor, que Agamben tomando-o apenas como uma "irônica denominação" acabe passando por alto a origem contemporânea de um termo que, pelo visto, lhe é muito caro. Entre as questões que restam de Auschwitz, poder-seia, sem ironias, dizer: a Palestina. O termo "muçulmano" pode ter sido já empregado nas Cruzadas, mas modernamente ele passou a ser usado pelo racismo sionista. Portanto, tem-se de registrar que a Palestina ocupada tem muito a ver com o termo "muçulmano" e que seu emprego já era bastante comum entre os judeus europeus, que por isso foi também usado em Auschwitz para se referir aos próprios coadjuvantes no infortúnio, como os sub-homens, os inferiores e os desprezíveis.

Segundo Max Horkheimer, a personalidade é um acontecimento histórico, mas então todo evento histórico pode mudar com o tempo e ser reinterpretado à luz de novos acontecimentos. Pode-se entender que a escuridão de Auschwitz supere de longe as tentativas de sua explicação, mas isso não vale para o que vem ocorrendo depois desse acontecimento sui generis. Ora, recorrendo às palavras de Agamben, o constante estado de exceção da população palestina sob o bando sionista está diluindo as imagens e a força dos testemunhos de Auschwitz. Agamben, é bom lembrar, aponta para a incapacidade de julgar os campos de concentração, mas só após os criminosos nazistas mais conhecidos terem sidos sentenciados e condenados à morte. Ou seja, tanto ele como Primo Levi tinham de encontrar na justiça humana possível um conforto para algo que, a rigor, não poderia ser julgado segundo os padrões tradicionais. Mas, uma pergunta subjaz à noção de vida nua em Agamben, que insiste na impossibilidade de sequer 
entender os campos de concentração com a terminologia tradicional: como julgar o que não se compreende?

Se considerarmos, porém, apenas o que precariamente pode ser julgado, então Auschwitz estará sempre, como tudo o que é histórico, sujeito a reinterpretações. Mesmo que se o considere como inominável, as imagens e descrições que mais se aproximam desse evento singular serão tomadas sempre em perspectiva. E, nesse sentido, Auschwitz também se tornou um álibi para os crimes do sionismo. Mas pode o crime inominável do nazismo servir de cobertura para os crimes nomináveis do sionismo? Pode sim. O ataque sionista ao Líbano (2006) e depois à Faixa de Gaza (2009) tornaram-se capítulos memoráveis na história universal da covardia e mostram que para os palestinos, isto é, os muçulmanos de nome e origem, restou o pior dos mundos, pois, ao contrário do campo de concentração nazista que fisicamente acabou, eles estão, sob a ocupação sionista, confinados e divididos em vários "guetos de Varsóvia". A violência sofrida e as tentativas de sua desmoralização pelo bando soberano israelense não têm fim visível. Sobre isso vale lembrar o que alguém já disse: "Mais vale um fim no horror do que um horror sem fim". 


\section{Notas}

${ }^{1}$ Trecho do curso "A metafisica como terra do nunca" proferido no PPG-UFSC, $1^{\circ}$ semestre de 2008.

${ }^{2}$ Agamben, G. A linguagem e a morte, Belo Horizonte: Editora da UFMG, 2006.

${ }^{3}$ Ver Alain Badiou, Deleuze o clamor do ser, Rio de Janeiro: Zahar Editor, p. 140. Segundo Deleuze: "Sempre houve apenas uma proposição ontológica: o Ser é unívoco. Nunca houve mais do que uma única ontologia, a de Duns Scotus, que dá ao ser uma única voz" (op. cit., p. 125). Posição, aliás, radicalmente distinta da de M. Bakhtin e mesmo de Aristóteles para quem o ser se diz de vários modos. Seja como for, é isso que Agamben pretende afastar.

${ }^{4}$ E aqui já nos deparamos com uma deficiência de seu livro quando ameaça tomar um autor que nunca é de fato considerado: o Wittgenstein do Caderno Azul e das Investigações filosóficas e a sua crítica contundente do modelo objeto-designação. Ora, esse "esquecimento" de Agamben o ajudou também a contornar o problema do "assassinato da filosofia", como advertira Deleuze sobre Wittgenstein.

${ }^{5}$ HEIDEGGER, Martin, Sein und Zeit, Tübingen: Max Niemeter Verlag, 1986. Abreviado como SZ.

${ }^{6}$ As suas interpretações poéticas são relevantes para mostrar seu caráter de autor "epigonal”, pois quando toma os trovadores medievais desde a perspectiva da revolucionária experiência cristã do amor, entendida de modo fenomenológico existencial, Agamben é bastante elucidativo (ainda que Bertrand de Born, por exemplo, cante não só o amor Cortez, mas a guerra e a violência); mas quando Agamben parte para a tragédia grega e a poesia leopardiana, mostra-se, em sua obra, não a conexão ou convívio, mas antes a confusão entre filosofia e poesia. No esforço para encontrar aspectos filosóficos num poema de Leopardi, Agambem toma as palavras poéticas, mas para simplesmente convertê-las em superconceitos filosóficos. Ora, não é por que existem num poema palavras como "pensamento", "nada", "naufrágio" que o poema se aproxima dos limites da linguagem ou indica o naufrágio do sentido. Num poema as palavras "morte", "cadeira" ou "maçã" não podem ter distintos níveis ontológicos e, muito menos não é porque houve uma mudança para melhor na vida de Leopardi, que seu problema com o "pensamento" ficou também mais leve. Ora, não é biografia que explica um poema. Antes as biografias dependem da poesia. É a poesia que tem a prioridade de sentido e é precisamente isso que a aproxima da filosofia. Portanto, não é por ter palavras de cunho filosófico que um poema filosofa. Ingenuidade difícil de aceitar em Agamben, autor que se proclama versado em estética. Ora, porque um poeta usa a palavra "profundo" é ele profundo? Por que usa a palavra "nada" é ele niilista? Mas não é nosso objetivo tratar desse assunto aqui e sim chamar a atenção de para o cunho pós-metafísico com o qual Agamben focaliza superfluamente alguns temas do nosso tempo.

${ }^{7}$ AGAMBEN, G. Homo Sacer, Editora UFMG, 2007, p. 173.

${ }^{8}$ AGAMBEN, op. cit., 2007, p. 11.

${ }^{9}$ NANCY, J-L. L’impératif catégorique, Paris, 1983, p. 149-150.

${ }^{10}$ AGAMBEN, G. O que resta de Auschwitz, São Paulo: Boitempo Editorial, 2008.

${ }^{11}$ Em SZ, Heidegger afirmara: "Interpretar o movimento de passagem do ser-aí para o ente apenas simplesmente dado perde a base fenomenal na medida em que o ente remanescente não é uma mera coisa corpórea. Do ponto de vista teórico, mesmo o cadáver dado é ainda objeto possível de análise patológica, cuja tendência de compreensão se orienta, não obstante, pela ideia de vida. O ente ainda simplesmente dado é "mais" do que uma coisa material, destituída de vida (lebloses). Nele se encontra algo não vivo, que perdeu a vida (Unlebendiges) (SZ, p. 238)". Ou seja, o abandono radical na impessoalidade do campo de concentração retira até mesmo a intimidade que cada ser-aí singular tem com a sua própria morte, pois "o chegar-ao-fim encerra em si um modo de ser absolutamente insubstituível para cada ser-aí singular” (SZ, p. 242). Ou seja, na situação de abandono radical do muçulmano sequer existe o vazio de um ainda-não. Na completude do abandono não há mais futuro e, por conseguinte, apagam-se também o passado e o presente. 
${ }^{12}$ Essa passagem dos Beiträge zur Philosophie, citada por Agamben (na tradução para o português), não se encontra
na página 115 da edição de 1989. Ver: HEIDEGGER, M. Beiträge zur Philosophie (vom Ereignis), Frankfurt am Main: Vittorio Klostermann, 1989.

${ }^{13}$ AGAMBEN, G. Homo sacer, p. 190.

14 SMITH, W. Robertson. Lectures on the religion of the semites, Londres: 1894, p. 453-454. Citado por AGAMBEN, 2007, p. 85.

${ }^{15}$ É muito estranho como tanto Habermas quanto Agamben passam por alto as obras do historiador israelense Ilan Pape que explica, inclusive com "testemunho" pessoal, a origem terrorista e genocida do sionismo e do Estado de Israel.

${ }^{16} \mathrm{Na}$ introdução à edição brasileira de O que resta de Auschwitz, Jeane Maria Gagnebin reconhece a origem obscura do termo "muçulmano" e apenas timidamente arrisca-se a dizer que, em todas as laboriosas tentativas de explicação, não consegue ouvir outra coisa que "uma certa desforra de caráter racista na boca das vítimas do anti-semitismo" (AGAMBEN, 2008, p. 13). Ora, a Senhora Gagnebin passa por alto que essa desforra não se dirigiu aos algozes do semitismo, mas aos indefesos e ingênuos camponeses muçulmanos que viviam na Palestina. Desse modo, essa comentadora é mais uma das cabeças formadas pela estratégia do sionismo disposto a fazer qualquer crime para, desmentindo a opinião de Foucault e Agamben, ocupar um território expulsando dali seu povo. O sionismo é um dos exemplos mais bem desenvolvidos da luta pelo "espaço vital" (Lebensraum), no caso do Eretz Israel. Para os palestinos, a sua própria terra foi transformada em vários campos de concentração. Através de chantagens de todo o tipo, ameaças e assassinatos tiveram de abandonar suas casas e propriedades. Os vilarejos invadidos também eram queimados para apagar a memória daqueles que ali viveram por centenas de anos. Mas se muitos foram embora, outros resolveram ficar e resistir ao bando sionista soberano.

${ }^{17}$ JONAS, Hans. Memorias, Madrid: Editorial Losada, 2005, p. 82. 